\title{
Experimenting with Dogme in a Mainstream ESL Context
}

\author{
Daniel Xerri ${ }^{1}$ \\ ${ }^{1}$ University of Malta, Malta \\ Correspondence: Daniel Xerri, Room 346A, Department of English, University of Malta Junior College, Guze \\ Debono Square, Msida, MSD 1252, Malta. Tel: 356-992-07492. E-mail: daniel.xerri@um.edu.mt
}

\author{
Received: May 12, 2012 Accepted: June 3, 2012 Online Published: July 25, 2012 \\ doi:10.5539/elt.v5n9p59 URL: http://dx.doi.org/10.5539/elt.v5n9p59
}

\begin{abstract}
This article explores the use of Dogme with postsecondary ESL students in a mainstream educational institution. By means of a small-scale action research study it was found that in spite of its reputation for being somewhat unconventional, Dogme can also be incorporated in an exam preparation course and allow students to benefit not only from the interaction that acts as a motor for the entire lesson but also from the emphasis put on emergent language. This article discusses how this materials-light and learner-centred teaching approach has the potential to empower the teacher to capitalise on students' contributions and help them engage with language in a meaningful manner.
\end{abstract}

Keywords: Dogme, ELT, postsecondary, emergent language, ESL, learner centred

\section{Introduction}

Dogme revolves around the idea that a successful lesson need not necessarily be materials-driven but can actually be based on 'the 'raw materials' provided by the people in the room' (Meddings \& Thornbury, 2009, p. 7). Scott Thornbury launched Dogme in 2000 and his inspiration for this pedagogy was the Dogme 95 film movement, which championed a minimalist approach to filmmaking.

\subsection{Pre-Dogme}

I first became acquainted with Dogme after attending a symposium convened by Scott Thornbury at an international ELT conference in Brighton. Subsequently I followed an intensive teacher training diploma course in Barcelona and Dogme was one of the approaches I was encouraged to try out, albeit all too briefly. I had already been teaching English for seven years by then, mostly in secondary and postsecondary schools in Malta, but had never been sufficiently adventurous to stray from the safe methods by means of which I myself had been taught English as a student. These methods entailed the use of a transmissive assessment-driven approach to language teaching in which writing and reading skills were given exclusive priority and grammar was taught in a deductive manner. The years I had spent in mainstream education had shown me that most teachers and students rarely engage in activities associated with deep-end CLT and that the language learning experience was entirely governed by an impersonal syllabus and summative assessment. Teacher talk seemed to prevail over any other interaction pattern and whenever students made a contribution it was often because they were prodded by the teacher's questions.

Hence I decided that the best way in which I could enhance my teaching knowledge and skills and examine my attitudes and beliefs as a teacher was by embarking on a course leading to a diploma in ELT, what is perhaps considered to be one of the most challenging and rewarding qualifications in the field. Having already completed a PGCE and a number of other postgraduate qualifications, I did not strictly speaking need such a diploma in order to improve my job prospects. However, deep down I knew I needed to re-evaluate who I was as a teacher and what effect my beliefs and practices were having on my students. I was disillusioned with successive groups of students who gradually developed a satisfactory competence in reading and writing at an advanced level but who faltered or got tongue-tied when asked to express an opinion. Luckily, the main examination board in Malta decided that speaking skills were to start being assessed in the near future and the washback effect of this was that I (together with a number of colleagues I spoke to) realised that perpetuating a situation in which students were there to listen while the teacher talked was no longer tenable. I say 'luckily' but at the same time I am all too aware of the irony of seeking to effect change as a result of new examination demands. 


\subsection{Professional Interest}

I chose to adopt Dogme as an approach with my students because even though I had heard a lot about its pedagogical tenets I had never actually mustered the courage to use it during my lessons. Its main attraction for me was the challenge of 'a pedagogy of bare essentials, that is, a pedagogy grounded in the local and relevant concerns of the people in the room' (Thornbury, 2006, p. 70). Prior to discovering Dogme I had always based my teaching on a surfeit of materials, which resulted in lessons during which I felt rushed and under pressure to use all the material I had incorporated in my plan. I gradually realised that by teaching in this way I did not have enough time in which to adequately respond to students' problems and to effectively deal with their language production. Moreover, my teaching was materials-driven and not learner-centred and this meant that I was failing to capitalise on my students as valid contributors to the learning experience.

As a non-native speaker of English I became interested in Dogme because it 'seeks to subvert...the idea that language teaching is about the transmission of perfect models of expression' (Meddings \& Thornbury, 2009, p. 84 ) of which only native speakers are capable. Dogme appreciates the role of non-native teachers who are capable of 'exploring and extending the learner's existing language capacity' because they possess the 'ability to see the target language through the learners' eyes' (Meddings \& Thornbury, 2009, p. 84).

In addition, I realised that Dogme could be highly useful for me as someone who typically teaches examination classes, especially because 'a more conversational, exploratory and hands-on approach to the exam syllabus can reap its own rewards' (Meddings \& Thornbury, 2009, p. 94). I became interested in the idea of using Dogme during some of my lessons because of the growing conviction that it can 'help to maintain engagement and enjoyment through what can be a stressful and somewhat monotonous time' (Meddings \& Thornbury, 2009, p. 95). In order to test the above notions I decided to engage in an experiment that would allow me not only to employ a different pedagogical approach to the one I was used to but also to reflect on my own development as a teacher.

\section{Theory and Practice}

Dogme ELT is based on three fundamental principles: it is conversation-driven, materials-light, and focuses on emergent language.

\subsection{Conversation-driven}

Thornbury (2000) suggests that 'Teaching should be done using only the resources that teachers and students bring to the classroom - i.e. themselves - and whatever happens to be in the classroom' (p. 2). This means that Dogme highlights the centrality of communication and dialogue and the need for teachers to respond to the fluctuations of the learning process within every lesson. It opposes the knowledge transfer model of education and does not view students as possessing a tabula rasa that the teacher is responsible for filling with learning. For Dogme practitioners 'Learning is a social and dialogic process, where knowledge is co-constructed' and 'mediated through talk' (Meddings \& Thornbury, 2009, p. 8).

Classroom interaction is what allows language to emerge given that when learners engage in conversation they are making use of language. This ties in with Hatch's (1978) idea that 'language learning evolves out of learning how to carry on conversations' (p. 404). Given that conversation is discourse, language teaching should underscore the importance of learning situations in which students are equipped for real-life language use by means of communicative activities. Dogme seeks to do this by foregrounding the idea that "when learners are communicating, communication should, first and foremost, be 'about themselves" (Meddings \& Thornbury, 2009 , p. 10). Moreover, conversation scaffolds learning and promotes socialisation and in this sense it acts as a means to an end not an end in itself.

\subsection{Materials-light}

Dogme is renowned for advocating a materials-light kind of teaching that frees the teacher from a sense of dependence on coursebooks and technology. Dogme is centred on the idea that students and teachers collaboratively construct learning but it is not entirely against the use of materials. However, by means of a materials-light approach 'the teacher frees the learning space for the kind of interactive, talk-mediated learning opportunities that are so crucial for language development' (Meddings \& Thornbury, 2009, p. 12). Dogme values the learners as texts and this manifests the influence of Freire's (1993) idea that 'The teacher is no longer merely the-one-who-teaches, but one who is himself taught in dialogue with the students, who in turn while being taught also teach' (p. 80). Hence the act of using very little or no materials whatsoever is empowering for both teachers and students.

A materials-light approach foregrounds classroom interaction and gives learners a voice. According to 
Ashton-Warner (1963) 'the more material there is for a child, the less pull there is on his own resources' (p. 118). Getting rid of unnecessary materials makes the learning experience 'so much simpler and clearer as a result. There's much more time for conversation...communication' (Ashton-Warner, 1963, p. 119). Thornbury (2005) contends that 'Materials-mediated teaching is the 'scenic' route to learning, but the direct route is located in the interactivity between teachers and learners, and between the learners themselves' (p. 3). The reason for which Dogme is critical of materials is because 'more often than not, they simply get in the way. They are a barrier. They inhibit dialogue' (Meddings \& Thornbury, 2003). Teachers who free themselves of a dependence on coursebooks probably believe that 'language is an emergent phenomenon, and that the learning of it is a jointly constructed and socially motivated process, contingent on the concerns, interests, desires, and needs of the user' (Meddings \& Thornbury, 2001). Such a view of language allows teachers to adopt a different view of their role in the classroom.

\subsection{Emergent Language Focus}

Dogme shares many of its conceptions regarding language learning with Communicative Language Teaching, whose most famous tenet is probably the one arguing that 'If the language teacher's management activities are directed exclusively at involving the learners in solving communication problems in the target language, then language learning will take care of itself' (Allwright, 1979, p. 170). Dogme underscores the notion that language learning is not really a question of acquisition but rather one of emergence. According to Thornbury (2005) 'it is an organic process that occurs given the right conditions' (p. 3).

The teacher's job is to direct the students' attention to the emergent language and in so doing help students to activate their interlanguage and enable it to develop. For this to happen 'the language focus should emerge from, and not determine, the communicative needs of the learners' (Thornbury, 2005, p. 4). Hence Dogme is very much in favour of a focus on form approach and reactive teaching rather than pre-emptive teaching. Long (1991) explains that a focus on form 'overtly draws students' attention to linguistic elements as they arise incidentally in lessons whose overriding focus is on meaning or communication' (pp. 45-46). This means that teaching is responsive to the language generated during the lesson and that students' errors are seen as an opportunity for learning to take place. A focus on form is important because it helps learners 'to improve their accuracy, develop their fluency and extend their repertoire' (Meddings \& Thornbury, 2009, p. 60).

\section{Action Research}

After reflecting on my beliefs and practices as a teacher I devised a schedule of lessons that would provide me with the opportunity of experimenting with Dogme while not overdoing it. I planned to do a Dogme lesson at least once a month over the length of a scholastic year and to do the same lesson with two different classes of students aged 16-18. The lessons were delivered as part of a two-year postsecondary English course that students follow before enrolling at university. In order to gauge the effects of my Dogme lessons I decided to keep a journal in which I reflected on my teaching, the strengths and weaknesses of each lesson, and its outcomes. I also collected data from the students via feedback sheets and unstructured interviews.

\section{A Typical Lesson}

In order to highlight some of the results of my experiment with Dogme it would perhaps be sound to provide a concrete demonstration of how I sought to put its tenets into action and what typically emerged at the end of most lessons. One of the first Dogme lessons I did with my students was based on the idea of students expressing wishes about themselves, their families and friends, their school, their neighbourhood or town, and the world. It was adapted from Meddings and Thornbury (2009) and it served as a platform for successive Dogme lessons.

\subsection{Aims, Objectives and Outcomes}

In all my Dogme lessons I sought to achieve the following objectives:

- Use no materials and thus capitalise on my students' contributions;

- Distance myself from the transmission model of pedagogy;

- Make my lesson entirely learner-centred;

- Maximise interactivity between the learners and me, and between the learners themselves;

- Focus on emergent language;

- $\quad$ Provide students with sufficient wait time and processing time.

While planning my lessons I hoped that Dogme would ideally allow the learners to achieve the following:

- $\quad$ Contribute as fully as possible by conversing with their peers and me; 
- Feel that the lesson has allowed them to make a personal contribution;

- $\quad$ Feel that they are at the heart of the lesson;

- Learn the language that emerges during the course of the lesson.

Consequently, with regards to the lesson described hereunder for illustrative purposes, I envisaged its main aim to be that of enabling students to practise their speaking skills and, to a much lesser extent, their writing skills. By the end of the lesson they would have had an opportunity of describing different wishes by means of spoken (and written) language and to master any language that emerged during the lesson's activities. In communicative terms, the lesson aimed to allow students to talk about different wishes they had and to ask each other about these. By the end of the lesson students would have discussed a number of wishes with their peers and argued in favour and against certain wishes in order for the class to finally reach a consensus.

\subsection{Assumptions}

I expected the students to be familiar with the topic of wishes and to have the necessary vocabulary in order for them to discuss this topic with their peers. I also expected them to have mastered a number of expressions used when expressing wishes but if need be the model sentences I would be using during the first activity would allow weaker students to produce 'a high turnover of chunk-type language' (Thornbury, 1999, p. 102) during the subsequent activities. As part of this lesson's activities I expected the students to be able to share their personal opinion with their peers, find differences and similarities in opinion, and reach a consensus.

\subsection{Problems and Solutions}

During the planning stage I anticipated a number of problems concerning different aspects of the language learning experience and for each one I tried to come up with a possible solution.

Meaning: Some students might find it difficult to find the right vocabulary in order to express different wishes. If need be I would ask them to indicate any words that they required during the writing stage in order for them to be able to use them when expressing their wishes orally.

Form: They might find it difficult to understand how to form sentences by means of which they could express different wishes. Before actually asking them to do it on their own, I would model how to write sentences expressing personal wishes. These sentences would be left on the board for the duration of the writing activity so as to scaffold the students' own sentences.

Communication: During the main speaking activity some students might rely too heavily on the written sentences and thus fail to discuss their experiences in detail. In case students were to fail to elaborate on their wishes during the main speaking activities, I would encourage individual students to do so by asking them questions and indicating that they should address the rest of their group.

Different abilities: Some students might finish the writing activity more quickly than others. Hence early finishers would be asked to come up with other wishes they could think of, especially in relation to the two circles for which they had not yet expressed any wishes.

Procedure: The main speaking activities might not run as successfully as planned because students might not be finding differences and similarities or trying to reach a consensus about the most important wish. In this case I would ask them questions about this and lead them towards a consensus.

\subsection{Procedure}

\begin{tabular}{|c|c|c|c|}
\hline Stage & $\underline{\text { Time }}$ & Focus & $\underline{\text { Procedure }}$ \\
\hline Speaking & 5 & $\mathrm{~T}-\mathrm{s}$ & $\begin{array}{l}\text { Draw five large concentric circles on } \\
\text { the board. In the inner circle, write } \\
\text { Me, then My family and friends, then } \\
\text { My school, then } \\
\text { city/neighbourhood, and in the } \\
\text { outermost circle, The world. Write a } \\
\text { wish for each circle and share with } \\
\text { the class. Encourage them to ask you } \\
\text { questions. }\end{array}$ \\
\hline
\end{tabular}

Writing $\quad 10 \quad \mathrm{~s} \quad$ Ask students to copy the diagram and to write down a wish for three of the circles. Check draft statements and

$\underline{\text { Aim }}$

To introduce students to the topic and to provide them with a model.

To enable students to write the wishes they would like to share with 


$\begin{array}{lll} & & \text { help with language whenever their peers. } \\ \text { necessary. }\end{array}$

to elaborate on the reasons for each wish. Encourage them to find differences and similarities.

Speaking $10 \quad$ S-s $\quad \begin{aligned} & \text { Ask different students to report back } \\ & \text { to the class and ask them to talk about } \\ & \text { reasons, similarities and differences. }\end{aligned}$

\begin{tabular}{|c|c|c|c|}
\hline Speaking & 5 & s-s & $\begin{array}{l}\text { Encourage students to adopt a single } \\
\text { wish for their city. They discuss this } \\
\text { in groups and have to reach a } \\
\text { consensus. }\end{array}$ \\
\hline
\end{tabular}

Speaking $\quad 10 \quad$ T-s-s Ask the different groups to report back to the class and write each wish on the board. Encourage the class to discuss these wishes, each group arguing for their own wish or else agreeing with the others. The class has to reach an agreement as to which wish is the most important.

\subsection{Lesson Evaluation}

The above lesson was on the whole quite successful because I managed to achieve my objectives and provide students with a satisfactory learning experience. The lesson was highly learner-centred and it bolstered my faith in Dogme as a pedagogical approach with the potential of enabling teachers to distance themselves from transmissive teacher-centred methods.

\subsubsection{Strengths}

From the very start the lesson was impelled by the idea that 'learners bring the lesson with them - in the 'rough form' of their language and lives - and the teacher helps them to shape it into a learning experience' (Meddings \& Thornbury, 2009, p. 24). I wanted the students to share their wishes with the rest of the class and hence I started by personalising the first activity and talking about some of my wishes. In this manner I managed to spark interest in the students and set a model for their own personalisation of language in subsequent stages. Gerngross, Puchta and Thornbury (2006) advise teachers that 'language is only memorable when it has been 'owned" (p. 8) but for this to work successfully it is better for the teacher to start with a personal example.

The first activity also allowed me to model some of the language that I wanted the students to produce during the writing activity. Even though whilst monitoring the latter I had to provide students with the necessary assistance in relation to lexis and grammar, this did not undermine the essential emphasis on interactivity at the heart of the lesson. The writing stage (and the subsequent activities) allowed me to react to emergent language and thus to adopt a focus on form approach without getting bogged down in lengthy grammar explanations. This kind of practice ties in with the idea that one of the teacher's roles during a Dogme lesson is 'to optimise language learning affordances, by...directing attention at features of the emergent language' (Thornbury, 2005, p. 3). The students' feedback indicated that they felt they had gained something concrete from the lesson in terms of language learning and this is probably a result of the kind of methods I used when focusing their attention on emergent language.

The speaking activities that followed gave students plenty of opportunities for contributing as fully as possible by discussing the lesson's topic with their peers and myself. In this sense my lesson fit in nicely with the idea that 'Allowing learners to express themselves, encouraging them to do this to the best of their ability, and showing them how they can do it more effectively, is the essential work of the unplugged teacher' (Meddings \& 
Thornbury, 2009, p. 24). Maximising interactivity was one of my key objectives and I tried hard to achieve this because I have convinced myself that nothing 'should interfere with, or inhibit, the free flow of participant-driven input, output and feedback' (Thornbury, 2000, p. 2). Hence during the open class discussions forming part of this lesson I tried as much as possible to step back and allow the students to lead the discussion. The students' feedback indicated that they found this lesson particularly interesting because they could interact with one another and learn new things about each other.

Whenever I asked questions I made sure to give students enough wait time; to remind myself that students require plenty of time to process my questions and formulate an answer I even mentally counted the seconds before reformulating my question if no answer was forthcoming. I did this because of the idea that 'increasing wait time enhances cognitive processing' (Ormrod, 2005, p. 110), especially with students who have limited English proficiency.

Moreover, I sought as far as possible to encourage students to ask each other questions and genuinely agree and disagree with one another's views. This on the whole was quite successful because even though students initially tried to explain why their wish was more significant than that of the other groups they ultimately did reach some kind of consensus. By means of eye contact I encouraged students to respond to one another and I feel that this was a means by which I distanced myself from unnecessary teacher talk.

\subsubsection{Weaknesses}

One of the main weaknesses of this lesson was the fact that I probably planned too many activities and hence ended up not being able to do the last activity as satisfactorily as possible. Given that the students seemed to be enjoying the open class discussion of each groups' similarities and differences I chose not to curtail this activity and move on to the last one. I made this decision based on the idea that the students should be the ones to dictate the pace of the lesson and not the teacher.

Another weakness was that I could probably have done more with the emergent language produced by the students. Even though the students did benefit from the focus on form approach I adopted during the different activities, I could have perhaps put up more language on the board for us to discuss.

\section{Outcomes}

The above lesson illustrates how my use of Dogme with postsecondary students yielded a number of benefits that are in line with the three principles on which this pedagogical approach is based. By reflecting on my lessons I came to realise that they were truly conversation-driven. Even though at first it was somewhat of a struggle for me to take a backseat and avoid interrupting the flow of conversation, gradually I realised that the students were developing the confidence to forge ahead without my constant guidance. A number of students commented on this when interviewed. Nick, for example, mentioned that he found it 'amusing that it's so easy to have a conversation with someone I don't know that well but still have a common topic to talk about'. Alison claimed that she 'liked the fact that it actively challenged me to maintain a conversation with a complete or almost complete stranger'. I deemed this to be such a rewarding experience that I was impelled to reposition myself in the classroom, from being a controller to someone who could switch between a variety of roles that for the most part foregrounded the students' contribution.

The act of sustaining a conversation for a number of minutes initially seemed like a daunting task for some students and this is probably because they had never really been asked to take the lead and use the L2 for longer than a brief answer to the teacher's questions. Sarah explained that 'It felt a bit strange for me since I rarely speak English when I engage in conversation' while Donovan 'found it interesting and exciting as I have never really done an activity like this before. We barely talk at school'. For students like Neil the Dogme lessons helped them to overcome their inhibitions about using the L2: 'I believe that as an activity it was perfect because it broke down the walls that were put up by us because we were scared of talking in English to others, afraid of what they would think'. On the other hand, someone like Paul felt that these lessons confirmed what he believed about his proficiency in speaking the target language: 'I enjoyed it because it showed me how fluent I am when speaking English'. For a number of students the Dogme activities came to be seen as necessary because whilst conversing with their classmates they realised how rusty some of them were when it came to spoken proficiency. Daphne remarked that 'This lesson is important because it showed me how to have conversations in English, something which the majority of us need training in'. Elvin concurred by pointing out that 'Clearly some students need more of this kind of thing as their speaking is not that good'.

Quite a number of students appreciated the fact that the Dogme activities provided them with an opportunity for learning more about their classmates. Sarah, for instance, said that she felt 'more comfortable within the group 
now that I found we share similar opinions'. This sentiment was echoed both by Carmen, who was pleased 'that there are other people who have the same wishes as I do', and by Karl, who 'was surprised by what some of the others said. I never thought they'd have such wishes'. The pleasure of finding more about one's peers was usually seen as interconnected with the need for conversation-driven activities, as seen in this comment by Bradley: 'I found this activity quite useful because it helped me build a conversation with more confidence and I also learnt a lot more about my classmates'.

\section{Conclusion}

Despite the fact that my language teaching is essentially geared towards the needs of prospective examination candidates, after experimenting with Dogme I came to embrace the idea of using it as a means of counterbalancing my existing assessment-focused pedagogy. Even though the act of preparing students for examinations usually entails strict adherence to the syllabus and the use of past examination papers in the classroom, Dogme allows me to 'elicit, teach and practise the kind of structures that the exam will test, but to retain the immediacy and engagement of real content' (Meddings \& Thornbury, 2009, p. 95). This includes capitalising on the learners' own lives during my lessons and merging the syllabus with a focus on form approach. Most importantly, even when I am not be able to engage in a Dogme approach my teaching is still directed by an awareness of the three axiomatic principles discussed above. Meddings and Thornbury (2009) express the hope that 'by experimenting with [Dogme] in ways that are sensitive to your teaching context, you start to experience another way of being a language teacher' (p. 21). After experimenting with Dogme I can confidently claim that this is true in my case.

\section{References}

Allwright, R. (1979). Language learning through communication practice. In C. Brumfit, \& K. Johnson (Eds.), The communicative approach to language teaching (pp. 167-182). Oxford: Oxford University Press.

Ashton-Warner, S. (1963). Teacher. London: Virago.

Freire, P. (1993). Pedagogy of the oppressed. London: Continuum.

Gerngross, G., Puchta, H., \& Thornbury, S. (2006). Teaching grammar creatively. Cambridge: Cambridge University Press.

Hatch, E. (1978). Discourse analysis and second language acquisition. In E. Hatch (Ed.), Second language acquisition (pp. 401-435). Rowley, MA: Newbury House.

Long, M. (1991). Focus on form: A design feature in language teaching methodology. In K. De Bot, D. Coste, R. Ginsberg, \& C. Kramsch (Eds.), Foreign language research in cross-cultural perspective (pp. 39-52). Amsterdam: John Benjamins.

Meddings, L., \& Thornbury, S. (2001). The roaring in the chimney (or: what coursebooks are good for). Humanising Language Teaching, 3(5). Retrieved January 11, 2012, from http://www.hltmag.co.uk/sep01/sart8.htm

Meddings, L., \& Thornbury, S. (2003). What Dogme feels like. Humanising Language Teaching, 5(6). Retrieved January 11, 2012, from http:/www.hltmag.co.uk/nov03/sart1.htm

Meddings, L., \& Thornbury, S. (2009). Teaching unplugged: Dogme in English language teaching. Peaslake: Delta Publishing.

Ormrod, J. E. (2005). Educational psychology. Upper Saddle River, NJ: Pearson Prentice Hall.

Thornbury, S. (2000). A Dogma for EFL. IATEFL Issues, 153(2).

Thornbury, S. (2005). Dogme: Dancing in the dark? Folio, 9(2), 3-5.

Thornbury, S. (2006). An A-Z of ELT. Oxford: Macmillan. 